\title{
Expanding the phenotypic and molecular spectrum of RNA polymerase III-related leukodystrophy
}

Stefanie Perrier, HBSc, * Laurence Gauquelin, MD, FRCPC, * Catherine Fallet-Bianco, MD, Megan K. Dishop, MD, Mackenzie A. Michell-Robinson, MSc, Luan T. Tran, MSc, Kether Guerrero, MSc, Lama Darbelli, PhD, Myriam Srour, MDCM, PhD, Kevin Petrecca, MD, PhD, FRCSC, Deborah L. Renaud, MD, Michael Saito, MD, Seth Cohen, MD, Steffen Leiz, MD, Bader Alhaddad, MD, Tobias B. Haack, MD, Ingrid Tejera-Martin, MD, Fernando I. Monton, MD, PhD, Norberto Rodriguez-Espinosa, MD, Daniela Pohl, MD, PhD, Savithri Nageswaran, MBBS, MPH, Annette Grefe, MD, Emma Glamuzina, MD, and Geneviève Bernard, MD, MSc, FRCPC

Neurol Genet 2020;6:e425. doi:10.1212/NXG.0000000000000425

\section{Abstract}

\section{Objective}

To expand the phenotypic spectrum of severity of POLR3-related leukodystrophy and identify genotypephenotype correlations through study of patients with extremely severe phenotypes.

\section{Methods}

We performed an international cross-sectional study on patients with genetically proven POLR3-related leukodystrophy and atypical phenotypes to identify 6 children, 3 males and 3 females, with an extremely severe phenotype compared with that typically reported. Clinical, radiologic, and molecular features were evaluated for all patients, and functional and neuropathologic studies were performed on 1 patient.

\section{Results}

Each patient presented between 1 and 3 months of age with failure to thrive, severe dysphagia, and developmental delay. Four of the 6 children died before age 3 years. MRI of all patients revealed a novel pattern with atypical characteristics, including progressive basal ganglia and thalami abnormalities. Neuropathologic studies revealed patchy areas of decreased myelin in the cerebral hemispheres, cerebellum, brainstem, and spinal cord, with astrocytic gliosis in the white matter and microglial activation. Cellular vacuolization was observed in the thalamus and basal ganglia, and neuronal loss was evident in the putamen and caudate. Genotypic similarities were also present between all 6 patients, with one allele containing a POLR3A variant causing a premature stop codon and the other containing a specific intronic splicing variant $(\mathrm{c} .1771-7 \mathrm{C}>\mathrm{G})$, which produces 2 aberrant transcripts along with some wild-type transcript.

\section{Conclusions}

We describe genotype-phenotype correlations at the extreme end of severity of the POLR3-related leukodystrophy spectrum and shed light on the complex disease pathophysiology.

\author{
Correspondence \\ Dr. Bernard \\ genevieve.bernard@mcgill.ca
}

\begin{abstract}
*These authors contributed equally to the manuscript.
From the Department of Neurology and Neurosurgery (S.P., L.G., M.A.M.-R., L.T.T., K.G., L.D., M. Srour, K.P., G.B.), McGill University; Child Health and Human Development Program (S.P., M.A.M.-R., L.T.T., K.G., L.D., M. Srour, G.B.), Research Institute of the McGill University Health Centre; Department of Pediatrics (L.G., L.T.T., K.G., L.D., M. Srour, G.B.), McGill University, Montreal, Quebec, Canada; Division of Clinical and Metabolic Genetics (L.G.), Division of Neurology, the Hospital for Sick Children, University of Toronto, Ontario, Canada; Department of Pathology (C.F.-B.), CHU Sainte-Justine, Université de Montreal, Quebec, Canada; Division of Pathology and Laboratory Medicine (M.K.D.), Phoenix Children's Hospital, AZ; Department of Human Genetics (L.T.T., K.G., L.D., G.B.), McGill University, Montreal, Quebec, Canada; McGill University (K.P.), Brain Tumour Research Center Montreal Neurological Institute and Hospital, Quebec, Canada; Department of Neurology (D.L.R.), Department of Clinical Genomics, Department of Pediatrics, Mayo Clinic, Rochester, MN; Department of Pediatrics (M. Saito), University of California Riverside School of Medicine, Riverside Medical Clinic, CA; Department of Pediatrics (S.C.), Beaver Medical Group, Redlands, CA; Division of Pediatric Neurology (S.L.), Department of Pediatrics, Klinikum Dritter Orden, Munich, Germany; Institute of Human Genetics (B.A., T.B.H.), Technische Universität München, Munich, Germany; Institute of Medical Genetics and Applied Genomics (T.B.H.), University of Tübingen, Germany; Department of Neurology (I.T.-M., F.I.M., N.R.-E.), Hospital Universitario Nuestra Señora de Candelaria, Santa Cruz de Tenerife, Canary Islands, Spain; Department of Neurology (D.P.), Children's Hospital of Eastern Ontario, University of Ottawa, Ontario, Canada; Department of Pediatrics (S.N.) and Department of Neurology (A.G.), Wake Forest School of Medicine, Winston-Salem, NC; Adult and Paediatric National Metabolic Service (E.G.), Starship Children's Hospital, Auckland, New Zealand; and Division of Medical Genetics (G.B.), Department of Specialized Medicine, Montreal Children's Hospital and McGill University Health Centre, Quebec, Canada.
\end{abstract}

Go to Neurology.org/NN for full disclosures. Funding information is provided at the end of the article.

The Article Processing Charge was funded by the Foundation of Stars.

This is an open access article distributed under the terms of the Creative Commons Attribution-NonCommercial-NoDerivatives License 4.0 (CC BY-NC-ND), which permits downloading and sharing the work provided it is properly cited. The work cannot be changed in any way or used commercially without permission from the journal. 


\section{Glossary}

nc-RNA = noncoding RNA; NMD = nonsense mediated decay; POLR3-HLD = RNA polymerase III-related hypomyelinating leukodystrophy; tRNA = transfer RNA.

RNA polymerase III-related hypomyelinating leukodystrophy (POLR3-HLD; MIM: 607694, 614381, 616494), or 4H leukodystrophy, is one of the most common hypomyelinating leukodystrophies, typically associated with the cardinal clinical features of hypogonadotropic hypogonadism and hypodontia. ${ }^{1-3}$ POLR3-HLD commonly presents in childhood, with motor delay or regression, prominent cerebellar features, mild pyramidal signs, and variable cognitive involvement. ${ }^{1}$ Typical brain MRI pattern includes diffuse hypomyelination with relative preservation (T2 hypointensity) of the anterolateral nucleus of the thalamus, globus pallidus, dentate nucleus, optic radiations, and pyramidal tracts in the posterior limb of the internal capsule, along with cerebellar atrophy and thinning of the corpus callosum. ${ }^{4-6}$

POLR3-HLD is caused by biallelic pathogenic variants in POLR3A, POLR3B, POLR1C, or POLR3K, which encode subunits of RNA polymerase III (POLR3), an enzyme responsible for transcription of several noncoding RNAs (ncRNAs), including transfer RNAs (tRNAs), 5S ribosomal RNA, U6 small nuclear RNA, 7S RNAs, and other small nucleolar RNAs. $^{7-15}$ The precise mechanism underlying the pathogenesis of hypomyelination remains to be fully elucidated; 2 main mechanistic hypotheses include (1) defects in transcription capability of POLR3 causing disruptions in tRNA levels, thereby altering global translation during myelination, which require large production of essential myelin proteins, or (2) impairments in specific POLR3-transcribed nc-RNAs required for myelin development. ${ }^{7,10,16}$

Here, we expand the phenotypic spectrum of POLR3-HLD through description of clinical, radiologic, and molecular features of six patients with an extremely severe phenotype and present functional and neuropathologic investigations on one patient.

\section{Methods}

\section{Patients and study design}

An international cross-sectional study was performed between 2016 and 2019, including a retrospective chart review of 6 patients (P1-6) from 5 families with atypical phenotypes identified from a repository of genetically proven POLR3HLD patients.

\section{Standard protocol approvals, registrations, and patient consents}

This research was approved by the Montreal Children's Hospital and McGill University Health Center Research Ethics Boards (11-105-PED; 2019-4972). Informed consent was obtained from all patients or legal guardians.

\section{Neuroradiology}

Brain MRI review was performed on latest available scans by L.G. and G.B. based on previously published criteria for hypomyelination and POLR3-HLD imaging characteristics. ${ }^{1,5,6,17-19}$ The earliest studies were also analyzed when available. Only one study was available for P5 and P6.

\section{Neuropathology}

Neuropathologic investigations were performed on postmortem brain tissue from P2; details are provided in supplemental methods (links.lww.com/NXG/A257).

\section{Genetic analysis}

Variants in POLR3A were identified by exome sequencing using genomic DNA extracted from blood samples, according to standard protocols. Variants were validated by Sanger sequencing and analyzed for familial segregation when DNA was available.

\section{Cell culture and cycloheximide treatment}

To evaluate the presence of nonsense mediated decay (NMD), fibroblasts derived from P2 were subjected to treatment with cycloheximide. Experimental details are described in supplemental methods (links.lww.com/NXG/A257).

\section{Western blot}

Immunoblots were performed using brain tissue protein extracts of P2 and an age/sex-matched control. Detailed protocols are outlined in supplemental methods (links.lww. com/NXG/A257).

\section{Data availability}

Data supporting this study's findings are available on reasonable request. Raw data from participants (i.e., raw genetic data and MRI data sets) are not made publicly available to protect patient privacy.

\section{Results}

\section{Clinical characteristics}

Patients 1-6 (P1-6) presented during infancy, between ages 1 and 3 months, with prominent feeding difficulties and failure to thrive. They exhibited severe developmental delay and motor regression before age 1 year. None achieved independent walking. Clinical characteristics are summarized in table 1 and table e-1 (links.lww.com/NXG/A257).

Of the 6 patients, $3(3 / 6,50 \%)$ had laryngomalacia and 2 underwent supraglottoplasty. All had dysphagia and required 
enteral tube feeding, with $5(5 / 6,83 \%)$ requiring a gastrostomy or gastrojejunostomy tube placement between ages 5 and 15 months. Four patients $(4 / 6,67 \%)$ developed severe respiratory insufficiency, and 3 required supplemental oxygen and/or noninvasive respiratory support between ages 5 and 15 months, with 1 later having a tracheostomy at age 13 months. In addition, 2 patients $(2 / 6,33 \%)$ had suspected paroxysmal episodes of dysautonomia, with excessive sweating and retching.

Non-neurologic features typical of POLR3-HLD included delayed dentition $(3 / 6,50 \%)$ and ophthalmologic abnormalities, including hyperopia and cortical visual impairment $(4 / 6,67 \%)$. All patients were too young for hypogonadotropic hypogonadism to be appreciated.

Neurologic examination revealed acquired microcephaly in 4 patients $(4 / 6,67 \%)$. Five $(5 / 6,83 \%)$ had a combination of axial hypotonia and upper motor neuron signs (spasticity and/or hyperreflexia) in the limbs. Generalized dystonia and/ or chorea was seen in all patients. Restricted upgaze and abnormal saccades were occasionally noted. Two patients exhibited hypomimia.

Progressive decline and respiratory complications led to the death of $\mathrm{P} 1, \mathrm{P} 2$, and $\mathrm{P} 3$ before age 2 years and $\mathrm{P} 4$ at age 3 years. P5 and P6 are alive and currently aged 5 and 3 years, respectively.

\section{Radiologic characteristics}

Brain MRI characteristics of P1-6 are summarized in table 2 and figure 1, which compares a typical POLR3-HLD MRI to P3. All 10 studies available for the 6 patients showed evidence of insufficient myelin deposition, but criteria for diffuse hypomyelination were not met (figure 1, E-K). ${ }^{6,17}$ Overall, there was more myelin than usually seen in POLR3-HLD and additional distinctive MRI characteristics. T2 hyperintensity of the hilus of the dentate nucleus, associated with T2 hypointensity (preserved myelination) of the dentate nucleus itself and peridentate region, was seen in all studies (figure 1F). In $9 / 10$ studies (90\%), the posterior brainstem exhibited similar features, with $\mathrm{T} 2$ hyperintensity (decreased myelin content) of the posterior medulla, posterior-inferior pons, and posterior aspect of the middle cerebellar peduncles, in a pattern suggestive of axonal degeneration (figure 1, F, I, and J). The latest imaging studies of 2 patients $(2 / 6,33 \%)$, obtained at ages 10 and 11 months, also revealed T2 hyperintensity of the red nucleus (figure $1 \mathrm{~K}$ ). In addition, $8 / 10$ studies (80\%) revealed abnormal signal of the lentiform nuclei, which appeared hyperintense on $\mathrm{T} 2$ sequences compared with gray matter and isointense to unmyelinated white matter. The same 8 studies also showed atrophy of the thalami (figure $1 G)$. The 2 scans without these findings were the 2 earliest studies (P2, age 2 months; P3, age 3 months); however, follow-up MRIs showed that these changes developed over time. Basal ganglia atrophy was seen only in the 5 latest scans obtained between ages 10 and 15 months. Cerebellar atrophy was not seen in any studies; however, mild to severe supratentorial atrophy was present in all cases (figure 1, G-H). No signs of pituitary involvement were noted.

\section{Neuropathology}

Preserved brain tissue of $\mathrm{P} 2$, who died at age 13 months from respiratory complications, was subjected to neuropathologic study (figure 2). The brain weighed $777 \mathrm{~g}$, below expected brain weight and comparable to typical weight at age 8 months. ${ }^{20}$ Macroscopic examination revealed normal symmetry with well-formed cerebral hemispheres and cerebellum (figure 2A). On gross examination, white matter was slightly reduced, but demonstrated normal appearance without gray discoloration or cavitation. The lateral ventricles and cerebellum had normal size (figure 2B), and corpus callosum thickness was normal for age.

Histologic analysis of the neocortex and hippocampus revealed some ischemic neurons because of the final hypoxicischemic injury preceding death. No mineralization of cortical neurons or evidence of inflammatory infiltrate, necrosis, or microglial nodules was present.

White matter demonstrated patchy areas of rarefaction with mild myelin pallor. Oligodendrocytes showed normal morphology and density in all studied areas, including pale areas, and features of demyelination were absent. White matter also exhibited diffuse astrocytic gliosis, both chronic (fibrillary) and subacute (protoplasmic), with activation of microglia but without macrophagic changes associated with phagocytic activity (figure 2, C-F). Changes in white matter appeared more severe in the parietal lobes (figure 2, C-D). No Rosenthal fibers or axonal spheroids were seen. Immunohistochemistry did not reveal any axonal lesions. The corpus callosum and corticospinal tracts demonstrated normal myelination.

Cellular vacuolization was seen in the thalamus and basal ganglia. Atrophy of the putamen was evident with enlarged Virchow-Robin spaces and severe neuronal loss, associated with both chronic and subacute diffuse gliosis, along with rare calcifications and considerable activation of microglia (figure 2, G-I). Discrete neuronal loss was evident in the caudate. Within the pallidum, numerous pale nuclei of Alzheimer type II glia were present due to the terminal anoxia, and no appreciable neuronal loss was evident. The adenohypophysis did not demonstrate pathologic abnormalities.

Hemisections of the brainstem demonstrated mild to moderate pyknosis in the pons and olivary nuclei of the medulla, consistent with acute ischemic changes. Patchy areas of reduced myelin were seen in the brainstem. The cerebellum demonstrated severe lesions of poorly myelinated white matter, with diffuse and mainly chronic (fibrillary) gliosis, but without notable morphological changes in oligodendrocytes (figure 2, J-L). The cerebellar cortex and dentate nucleus appeared normal, and Bielschowsky staining did not reveal 
Table 1 Clinical, MRI, molecular, and pathologic features associated with the typical and severe POLR3-related leukodystrophy phenotypes

Feature

Typical phenotype

Severe phenotype

Clinical characteristics

$3-4 y$

$1-3 \mathrm{mo}$

Age of death

Adulthood

$1-3$ y (2/6 patients still alive)

$\begin{array}{lll}\text { Symptoms at onset } & \text { Developmental delay and motor regression } & \text { Failure to thrive and developmental delay }\end{array}$

Developmental delay Mild to moderate Severe

\begin{tabular}{lll}
\hline Dysphagia Late Early and severe &
\end{tabular}

\begin{tabular}{lll}
\hline $\begin{array}{l}\text { Respiratory } \\
\text { insufficiency }\end{array}$ End of disease course Early and severe
\end{tabular}

insufficiency

$\begin{array}{lll}\text { Severe myopia } & \text { Very common } & \text { Too young }\end{array}$

Dental abnormalities Common Delayed dentition seen in $3 / 6$

Hypogonadotropic Common Too young

hypogonadism

Brain MRI Hypomyelination with preservation of specific structures, thinning of the corpus callosum, and cerebellar atrophy \begin{tabular}{ll}
\hline Genetics & $P O L R 3 A, P O L R 3 B, P O L R 1 C$, or POLR3K biallelic pathogenic variants \\
& $>200$ variants
\end{tabular}

Very atypical: more myelin than typical phenotype, supratentorial atrophy, and additional features including progressive abnormalities of the basal ganglia and thalami

POLR3A (NM_007055.3)

Compound heterozygous

Allele 1:

P1: c.2119C>T, p.Q707*

P2: c.1681C>T, p.R561*

P3: c.1051C $>$ T, p.R351*

P4: c.1051C>T, p.R351*

P5: c.601delA, p.I201Lfs*18

P6: c.3583delG, p.D1195lfs*47

Allele 2:

P1-6: $01771-7 C>G$

Pathology Prominent and diffuse decreased myelin, secondary axonal loss, and relative Prominent and diffuse decreased myelin, second
preservation of myelin in perivascular regions ${ }^{26}$

Patchy areas of decreased myelin, neuronal loss in the putamen and caudate, and vacuolization in the thalamus and basal ganglia 


\begin{tabular}{|c|c|c|c|c|c|c|c|c|c|c|c|c|c|}
\hline & & Typical POLR3-HLD & characteristics & & & Additional atypical & haracteristics & & & & & & \\
\hline ID & $\begin{array}{l}\text { Age at } \\
\text { MRI } \\
\text { (mo) }\end{array}$ & $\begin{array}{l}\text { Diffuse } \\
\text { hypomyelination }\end{array}$ & $\begin{array}{l}\text { Classic } \\
\text { T2 hypointensity } \\
\text { of specific } \\
\text { structures }\end{array}$ & $\begin{array}{l}\text { Thin } \\
\text { corpus } \\
\text { callosum }\end{array}$ & $\begin{array}{l}\text { Cerebellar } \\
\text { atrophy }\end{array}$ & $\begin{array}{l}\text { More myelin than } \\
\text { typically seen in } \\
\text { POLR3-HLD }\end{array}$ & $\begin{array}{l}\text { T2 hyperintense } \\
\text { hilus of the } \\
\text { dentate nuclei }\end{array}$ & $\begin{array}{l}\text { T2 hyperintense } \\
\text { lentiform nuclei }\end{array}$ & $\begin{array}{l}\text { T2 hyperintense } \\
\text { posterior- } \\
\text { inferior } \\
\text { brainstem }\end{array}$ & $\begin{array}{l}\text { T2 hyperintense } \\
\text { red nuclei }\end{array}$ & $\begin{array}{l}\text { Thalami } \\
\text { atrophy }\end{array}$ & $\begin{array}{l}\text { Basal } \\
\text { ganglia } \\
\text { atrophy }\end{array}$ & $\begin{array}{l}\text { Supratentorial } \\
\text { atrophy }\end{array}$ \\
\hline \multirow{2}{*}{$\begin{array}{l}\text { Patient } \\
1\end{array}$} & 6 & - & - & $+/$ mild & - & + & + & + & + & - & + & - & $+/$ mild \\
\hline & 15 & - & - & $+/$ mild & - & + & + & + & + & - & + & + & $\begin{array}{l}+/ \text { moderate- } \\
\text { severe }\end{array}$ \\
\hline \multirow[t]{2}{*}{$\begin{array}{l}\text { Patient } \\
2\end{array}$} & 2 & - & - & + & - & + & + & - & - & - & - & - & $+/$ mild \\
\hline & 7 & - & - & + & - & + & + & + & + & - & + & - & $\begin{array}{l}+/ \text { mild- } \\
\text { moderate }\end{array}$ \\
\hline \multirow[t]{2}{*}{$\begin{array}{l}\text { Patient } \\
3\end{array}$} & 3 & - & - & $+/$ mild & - & + & + & - & + & - & - & - & $+/$ mild \\
\hline & 10 & - & - & $+/$ mild & - & + & + & + & + & + & + & + & $\begin{array}{l}+/ \text { mild- } \\
\text { moderate }\end{array}$ \\
\hline \multirow[t]{2}{*}{$\begin{array}{l}\text { Patient } \\
4\end{array}$} & 8 & - & - & $+/$ mild & - & + & + & + & + & - & + & - & $\begin{array}{l}+/ \text { mild- } \\
\text { moderate }\end{array}$ \\
\hline & 11 & - & - & $+/$ mild & - & + & + & + & + & + & + & + & $\begin{array}{l}\text { +/mild- } \\
\text { moderate }\end{array}$ \\
\hline $\begin{array}{l}\text { Patient } \\
5\end{array}$ & 14 & - & - & + & - & + & + & + & + & - & + & + & $\begin{array}{l}+/ \text { moderate- } \\
\text { severe }\end{array}$ \\
\hline $\begin{array}{l}\text { Patient } \\
6\end{array}$ & 10 & - & - & $\begin{array}{l}\text { +/thin } \\
\text { isthmus }\end{array}$ & - & + & + & + & + & - & + & + & +/moderate \\
\hline
\end{tabular}



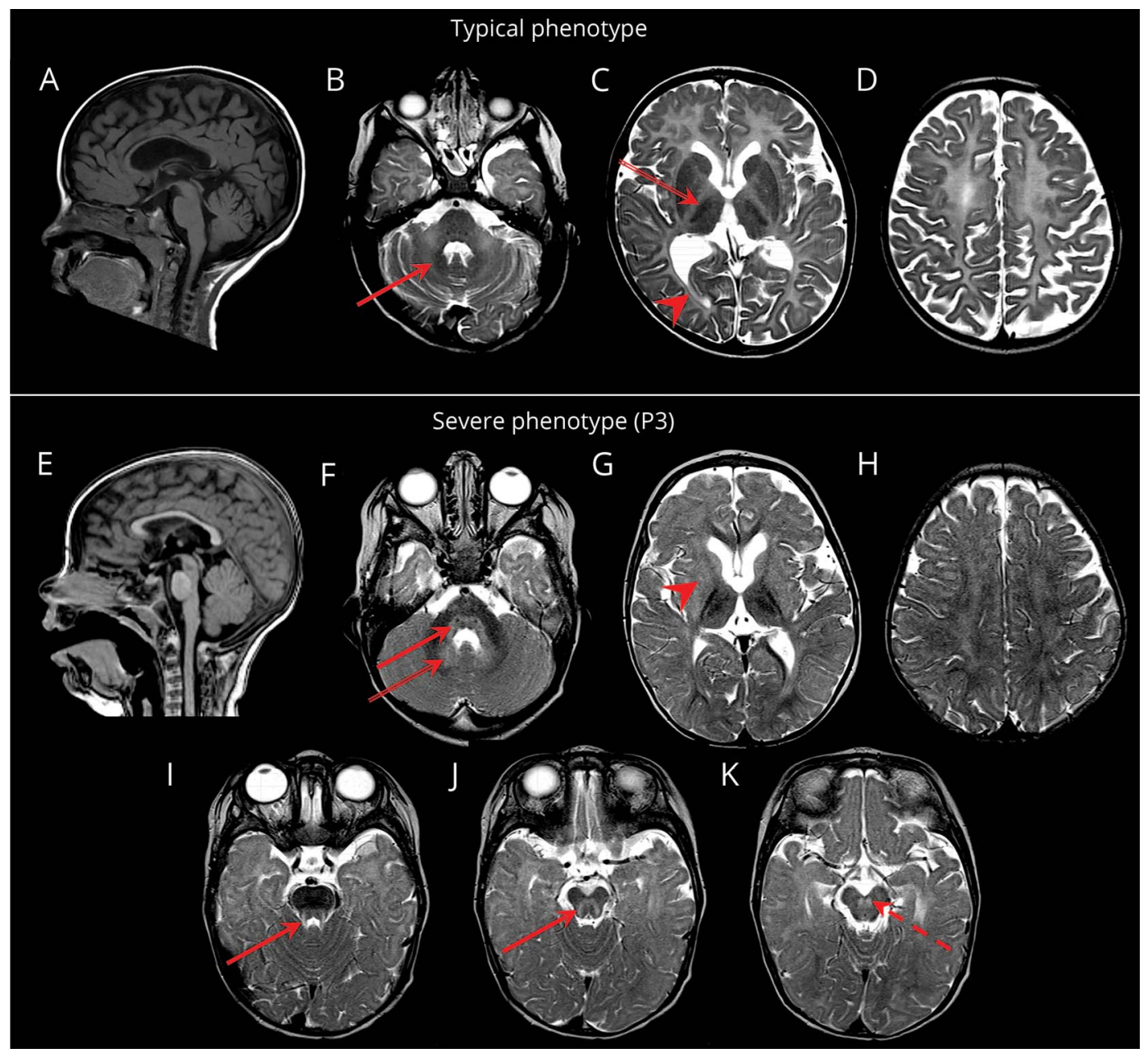

Sagittal T1-weighted (A, E) and axial T2-weighted (B-D, F-K) images. (A-D) Typical POLR3-HLD; MRI obtained at age 6 years. Hypomyelination with relative preservation (T2 hypointensity) of the dentate nucleus (red arrow; B), anterolateral nucleus of the thalamus (double-lined arrow; C), optic radiations (arrowhead; C), globus pallidus, and corticospinal tracts in the posterior limb of the internal capsule (not shown). Thinning of the corpus callosum and cerebellar atrophy are also seen. (E-K) Severe phenotype; MRI of patient 3 obtained at age 10 months. Mild insufficient myelin deposition, not meeting the criteria for diffuse hypomyelination. Loss of myelin (T2 hyperintensity) in the posterior brainstem (red arrows; F, I, J), red nucleus (red dashed arrow; K), and hilus of the dentate nucleus (double-lined arrow; F). Abnormal signal of the lentiform nucleus (arrowhead; G). Supratentorial atrophy (G-H) and diffuse atrophy of the basal ganglia and thalami $(G)$ are also seen.

clear evidence of decreased axons. Moderate pyknosis was seen in Purkinje cells; however, there was no appreciable loss of neurons. In the spinal cord, patchy areas of reduced myelin were noted.

\section{Genetic findings}

Each patient harbored a specific combination of compound heterozygous variants, including a variant causing a premature stop codon on one allele (P1: c.2119C $>\mathrm{T} / \mathrm{p} . \mathrm{Q} 707^{*}$, P2: c.1681C>T/p.R561*, P3\&4: c.1051C>T/p.R351*, P5: c.601delA/p.I201Lfs*18, P6: c.3583delG/p.D1195Ifs*47) and a specific intronic splicing variant on the other (P1-6: c.1771-7C >G). We hypothesized that this splicing variant was leaky as complete absence of POLR3A is incompatible with life. PCR amplification using complementary DNA from fibroblasts of $\mathrm{P} 2$ revealed 2 additional bands compared with controls (figure 3, figure e-1, links.lww.com/NXG/A257). Sequencing of bands revealed the presence of 2 aberrant transcripts resulting from abnormal splicing, including one lacking exon 14 causing a frameshift and premature stop codon (p.P591Mfs ${ }^{*}$ ) and the other lacking exons 13-14 causing loss of amino acids 548-637 (p.G548_Y637del). In addition, sequencing of the band corresponding to complementary DNA of wild-type length revealed the presence of both the nonsense transcript (c.1681C $>\mathrm{T} /$ p.R561*) and wild-type transcript, confirming the splice site variant is leaky (figure 3B). Thus, 4 transcripts were detected, with sequences corresponding to (1) wild-type, (2) the nonsense variant, and those resulting from aberrant splicing events including (3) lack of exon 14, and (4) lack of both exons 13-14 (figure 3C).

As transcripts containing nonsense variants are typically targeted for NMD, we hypothesized that the c.1681C>T/ p.R561* variant transcript was subjected to degradation. We 

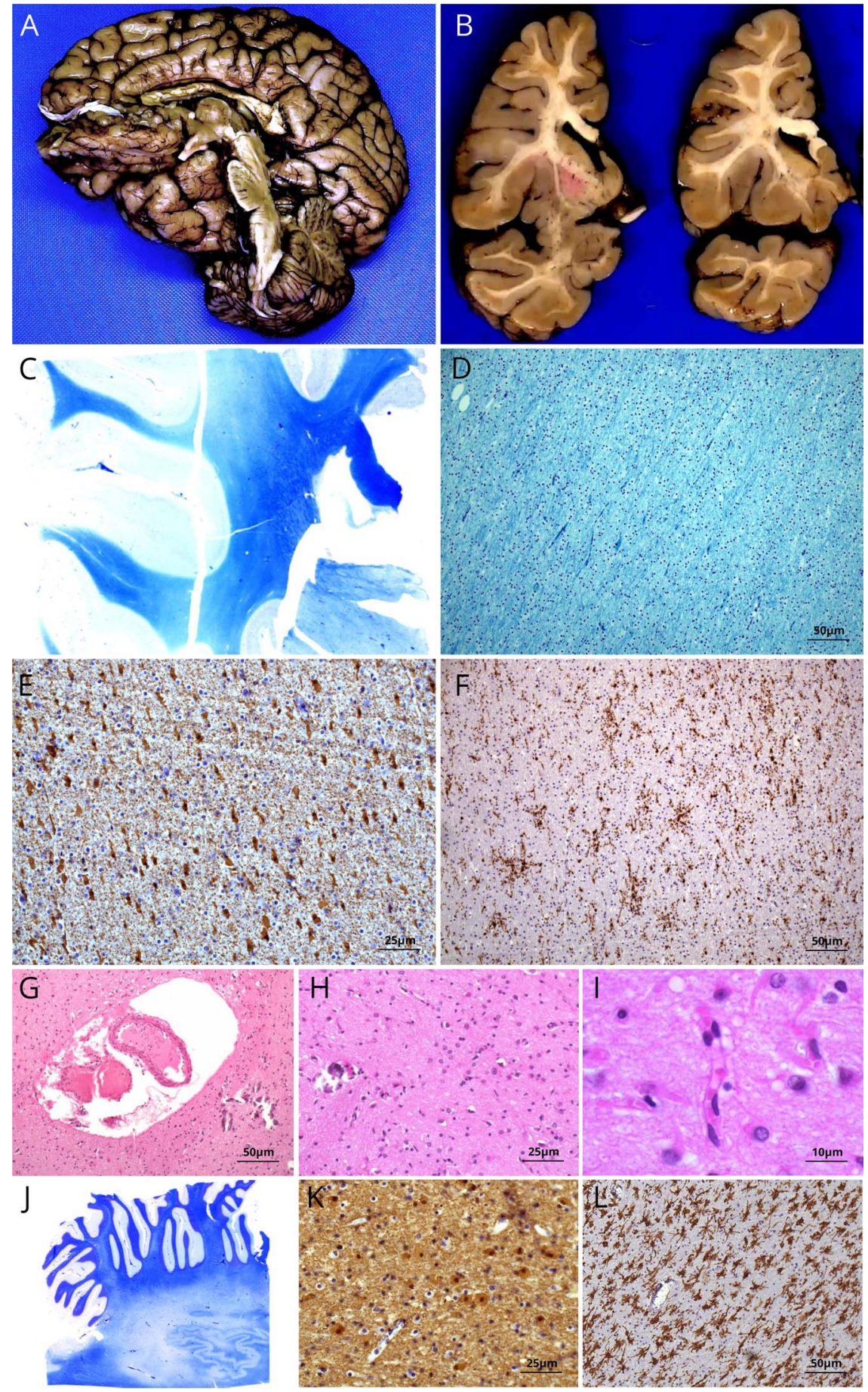

(A-B) Macroscopic appearance of the (A) right cerebral hemisphere, and (B) coronal sections showing a slight decrease of the volume of the white matter without appreciable ventricular enlargement. (C) Luxol fast blue-cresyl violet (Klüver-Barrera) staining demonstrating areas of poor myelination in the parietal white matter, but a normally myelinated corpus callosum. (D) Higher magnification of poorly myelinated white matter (10x), and (E) GFAP IHC revealing astrocytic gliosis (20x). (F) IBA1 IHC revealing activated microglia of the occipital white matter (10x). (G-I) Hemalun-phloxin staining revealing abnormalities of the putamen including $(G)$ enlarged Virchow-Robin spaces (10x), (H) neuronal loss and gliosis with few calcifications (20x), and (I) neuronal death (60x). (J) Luxol fast blue-cresyl violet-stained section of the cerebellum revealing hypomyelination of the cerebellar white matter surrounding the dentate nucleus. (K) GFAP IHC demonstrating gliosis in the cerebellar white matter $(20 \times)$, and (L) IBA1 IHC revealing activated microglia $(10 \times)$. GFAP = glial fibrillary acidic protein; IHC = immunohistochemistry. evaluated the presence of NMD in P2 fibroblasts compared with a control using cycloheximide, a compound that inhibits transcriptional elongation and consequently NMD. Following cycloheximide treatment, an increase in band 1 (corresponding to the wild-type transcript and nonsense variant transcript) was observed by semiquantitative PCR (figure 3B), indicating that the nonsense transcript is subjected to NMD under normal conditions.
Because complete lack of POLR3A is incompatible with life, we sought to determine whether the detected residual wild-type transcript would lead to wild-type protein expression. We performed immunoblot analysis on protein extracts from frozen brain tissue of P2 and an age/sex-matched control. To ensure detection of only wild-type full-length protein, we chose a POLR3A antibody with an epitope spanning amino acid residues 607-698. In $\mathrm{P} 2$, this antibody cannot bind to the 
abnormal protein products as the epitope binds to residues located in the truncated POLR3A region, i.e., after the premature stop codon ( $\left.\mathrm{p} . \mathrm{R} 561^{*}\right)$ and contained/semicontained in the deleted residues resulting from the splicing variant (p.P591Mfs*9, p.G548_Y637del). Thus, this antibody only allows detection of wild-type POLR3A (figure 3C, figure e-1, links.lww.com/NXG/A257). We observed reductions in average normalized POLR3A levels both in brain gray matter (84.7\% reduction, 95\% CI $=69.3 \%-100 \%, d=1.28$ ) and white matter (54.8\% reduction, $95 \% \mathrm{CI}=20.1 \%-89.5 \%, \mathrm{~d}=1.34)$ of P2 compared with control (figure 3, D and E). Gray matter displayed a greater reduction in POLR3A compared with white matter (average difference 29.9\%; 95\% CI $=0.7 \%-59.0 \%$; $\mathrm{d}=1.77)$.

\section{Discussion}

Here, we present an expanded spectrum of POLR3-HLD through description of 6 patients with a very severe phenotype and similar genotype. The dramatic clinical presentation, including prominent feeding and breathing difficulties and early death in 4 patients, is strikingly different from the typical POLR3HLD phenotype. A large phenotypic study of POLR3-HLD revealed typical onset at age 3-4 years with mild to moderate motor delay and/or regression. ${ }^{1}$ Dysphagia and respiratory insufficiency were late findings. Death typically occurred in adulthood, where the youngest to die was aged 8 years. ${ }^{1}$

The MRI pattern associated with this phenotype is distinct; despite very severe clinical manifestations, all patients had notably more myelin with different imaging features than typical POLR3-HLD. An evolving change in signal pattern was seen in the lentiform nuclei, with thalami atrophy, progressing to more diffuse basal ganglia atrophy. This correlated with the prominent basal ganglia and thalami pathologic abnormalities, including atrophy, calcifications, and severe neuronal loss in the putamina. Two patients also had red nuclei signal abnormalities. Recently, a similar MRI phenotype was described in patients with a c.1771-7C $>\mathrm{G}$ or c.1771-6C > G variant, in trans with a missense, nonsense, splice site, or synonymous variant. ${ }^{21,22}$ Clinical severity varied according to the trans POLR $3 A$ variant; patients homozygous for the splicing variant typically displayed a milder phenotype, whereas those harboring a trans loss of function variant displayed severe features with early onset. ${ }^{21-24}$ Of interest, patients homozygous or compound heterozygous for the c.1771-7C>G and/or c.1771-6C>G variants did not display white matter involvement and were described as only having the neuronal MRI features, including striatal involvement with caudate nucleus and putamen atrophy, and occasional red nuclei signal abnormalities. ${ }^{21-24}$ We hypothesize that these specific splicing variants cause a cell-specific effect (i.e., basal ganglia neurons) compared with other POLR3-HLD variants. This could explain why, when this variant is combined with a loss of function allele, patients with a severe phenotype have a specific MRI pattern (i.e., more myelin than the typical phenotype, with progressive basal ganglia involvement).

Neuropathologic examination revealed areas of reduced myelin in the brainstem. On MRI, all studies but one showed evidence of decreased myelin in specific posterior-inferior brainstem structures. Wallerian degeneration affecting specific tracts could at least partly explain these findings, although no clear axonal loss was documented on postmortem studies. The dentate nuclei appeared normal on neuropathologic analyses, consistent with the MRI pattern of preservation of the dentate nuclei and peridentate region. On MRI, reduced myelin was restricted to the hilus.

Although it is well known that hypomyelination is not obligate in POLR3-HLD, ${ }^{18,25}$ the discrepancy between the relatively mild insufficient myelin deposition and the diffuse supratentorial atrophy was highly unusual and consistent across all MRIs. Although previous studies have revealed that oligodendrocytes are primarily affected in the typical form of POLR3HLD, ${ }^{1,26}$ our patients' MRI and pathologic findings support the hypothesis that the severe form is primarily neuronal, with associated myelination deficits. We hypothesize that the pathophysiology associated with the severe phenotype varies substantially from typical POLR3-HLD and involves several neural cell types. As myelination is a complex process involving a multitude of signaling events between neurons and glia, it is possible that an increased disruption of POLR3 activity, or the production of aberrant transcripts, could manifest adversely in more cell types than in a milder deficit. It is known that dysregulation of transcription and translation-related genes is often associated with neurologic involvement, highlighting the importance of precise protein expression regulation during neural development. ${ }^{27-30}$ For example, defects in genes encoding aminoacyl-tRNA synthetases cause a variety of phenotypes, ranging from hypomyelination to brain malformations. ${ }^{31-38}$

Given the broad clinical spectrum of phenotypes associated with POLR3 deficiency, it is clear that pathogenic variants in POLR3 genes have distinct effects on various cellular processes. $^{25,39}$ Variants in POLR3A have been associated with phenotypes ranging from spastic ataxia-related disorders to neonatal progeroid syndrome, whereas variants in POLR3B have been associated with isolated hypogonadotropic hypogonadism, without hypomyelination or hypodontia, and a distinct phenotype of cerebellar hypoplasia with endosteal sclerosis. $^{25,39-41}$

In contrast to this extremely severe clinical presentation, we also identified 3 adults with a very mild phenotype and the same homozygous pathogenic POLR3B variant (c.1568T $>\mathrm{A}$ / p.V523E) in our patient cohort. These patients were all diagnosed incidentally in adolescence/adulthood, based on brain MRI performed for unrelated reasons, or through genetic investigation of typical POLR3-HLD affected relatives. They had minimal findings on neurologic examination, if any, and MRI revealed milder findings than usually seen in 
Figure 3 Molecular and protein level implications of pathogenic variants in patient 2

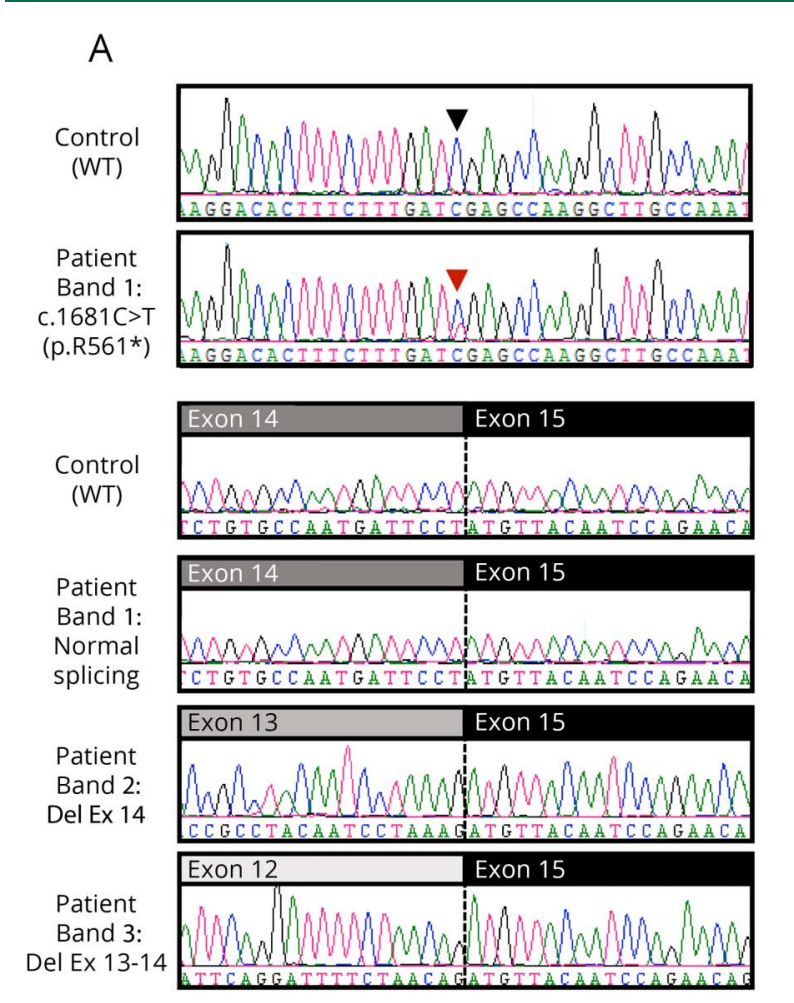

B

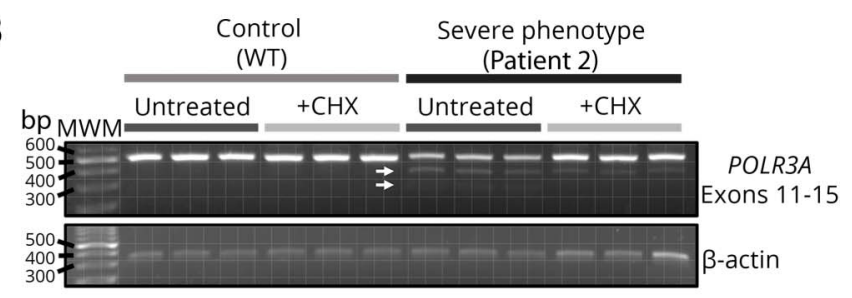

C

Nonsense variant Splice site variant

c.1681C $>$ T, p.R561* C.1771-7C >G

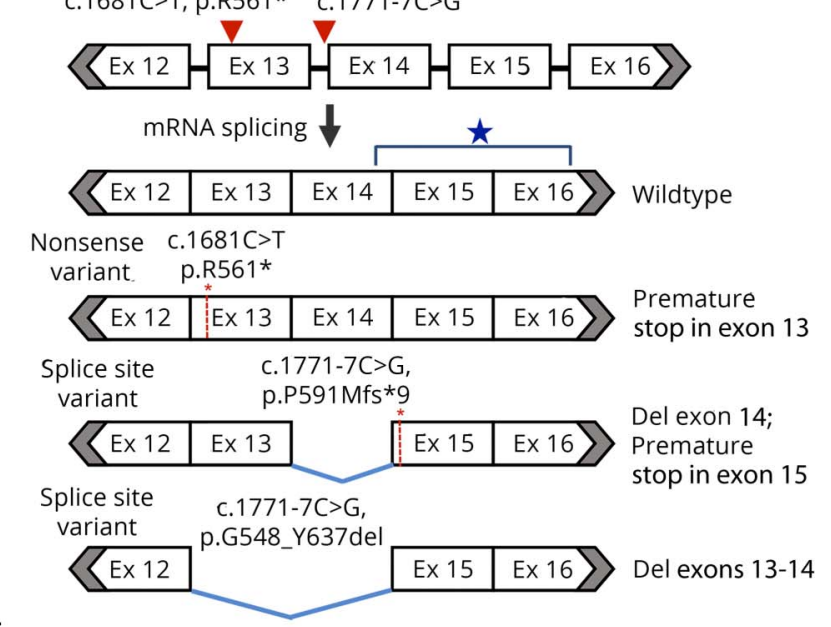

D

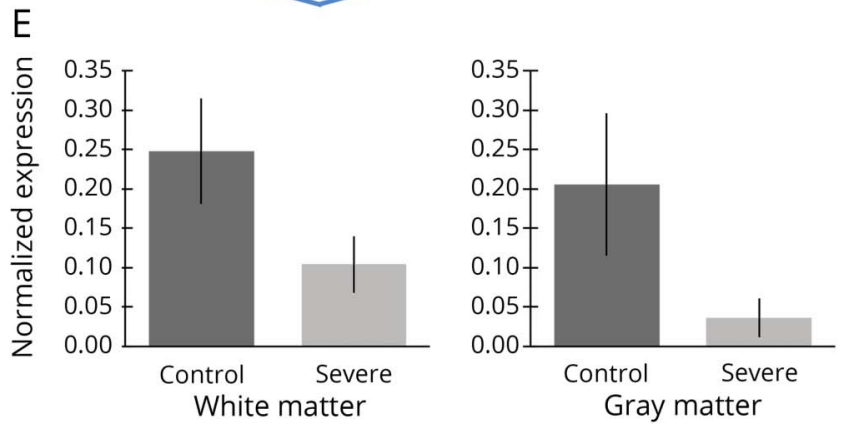

White matter

Gray matter

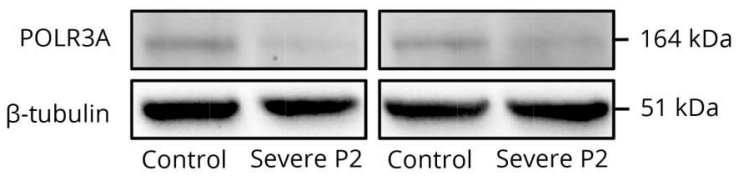

(A) Sanger sequencing results of RT-PCR products generated from patient 2 fibroblasts, as visualized by agarose gel electrophoresis in (B), in which 3 separate bands were excised and sequenced. In band 1, the presence of the POLR3A wild-type transcript is detected, as well as the transcript containing the paternally inherited nonsense variant (c.1681C > T; p.R561*), confirming that the splice site variant is leaky. Sequencing of the 2 additional bands confirms that the maternally inherited splice site variant (c.1771-7C>G) causes production of 2 additional transcripts, including 1 transcript with a deletion of exon 14, which produces a new open reading frame that results in a premature stop codon (p.P591Mfs*9), and the other containing a deletion of exons 13-14, which leads to the loss of amino acids 548-637 (p.G548_Y637del). (B) RT-PCR products with primers in POLR3A exons 11 and 15 revealing 2 additional bands in patient 2 fibroblasts compared with control fibroblasts. Cycloheximide treatment shows a stabilization of the mRNA containing the nonsense variant (band 1), confirming that it is targeted by NMD. $\beta$-Actin is shown as a loading control. (C) Schematic summary of each transcript detected following mRNA splicing. The starred region in the wild-type transcript denotes the POLR3A antibody epitope spanning from amino acids 607-698 for the immunoblots depicted in (D). (D) Immunoblots of protein lysates from frozen brain tissue of patient 2 (age 13 months) compared with that of an age/sex-matched control (age 14 months). Samples were collected from the subcortical white matter (left) and the cortical gray matter (right). (E) Normalized expression of POLR3A in the brain of patient 2 compared to that in the control. Chemiluminescent intensity of the POLR3A signal at $164 \mathrm{kDa}$ was normalized to the intensity of the $\beta$-tubulin signal at $51 \mathrm{kDa}$ for each blot. Average values of normalized protein expression are derived from 4 Western blot replicates, and error bars represent standard error of the mean. Full-length POLR3A is detected in both control and

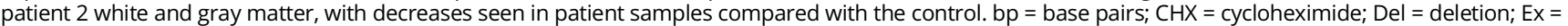
exon; $\mathrm{mRNA}=$ messenger RNA; NMD = nonsense medicated decay; P2 = patient 2; RT-PCR = reverse transcription PCR; WT = wild type.

POLR3-HLD. Two were previously described as having the mildest phenotype in a past large cohort study of POLR3$\mathrm{HLD},{ }^{1}$ and the third, who has not been reported, is an adult woman in her late $70 \mathrm{~s}$ for whom limited information is available. She is currently still ambulatory, and was able to reproduce, making it unlikely she had fertility concerns due to hypogonadotropic hypogonadism. She is described as having mild intellectual challenges and hearing loss from childhood of unknown etiology. She is also independent for all activities of daily living and maintained an active role in the care of her offspring. These cases highlight the extreme variability in disease severity of POLR3-HLD, which can range from very mild to exceptionally severe.

Each patient with a severe clinical presentation had a similar genotype, including a premature stop codon on one allele and 
a specific splicing variant (c.1771-7C > G) on the other. In our patient, we demonstrated that this variant is leaky and causes alternative splicing events producing 2 aberrant transcripts, corresponding to results in a past study that investigated this variant in homozygous form. ${ }^{25}$ It is thought that this variant creates a new enhancer binding site, and competition for enhancer binding at either the native acceptor splice site (SRp40 enhancer protein) or aberrant binding site (SC35 enhancer protein) is likely the cause of incomplete inactivation of the native acceptor splice site and leaky production of the wild-type transcript. ${ }^{23,25}$ We also confirmed that the transcript containing the nonsense variant was degraded by NMD. Moreover, as POLR3 is a housekeeping gene, complete loss of its function is incompatible with life, which is further supported by the embryonic lethal Polr $3 a$ knock-out mouse. ${ }^{42}$ Thus, leaky expression of some wild-type protein is not unexpected as all patients with a severe phenotype survived until early childhood. Although we were able to detect the production of some wildtype POLR3A protein in brain tissue of P2, protein levels were significantly decreased, supporting the hypothesis that minimal production of POLR3A is insufficient for proper neurodevelopment and growth. Less POLR3A protein was detected in gray matter compared with white matter, lending further support to our hypothesis that the severe phenotype is a primarily neuronal disorder.

These findings illustrate an expanded phenotypic spectrum of POLR3-HLD through presentation of patients with biallelic pathogenic variants in POLR3A and an extremely severe phenotype. Identifying genotype-phenotype relationships advances our understanding of the disease course, providing valuable information for clinicians and allowing patients and families to have proper genetic counseling. Our functional and pathologic studies shed light on the pathogenesis of the severe form of POLR3-HLD, opening the door for the development of targeted disease interventions.

\section{Acknowledgment}

The authors thank the patients and their families for participating in this study. This work would not have been possible without support from The Yaya Foundation for $4 \mathrm{H}$ Leukodystrophy. The authors acknowledge the McGill University and Genome Quebec Innovation Center.

\section{Study funding}

This study was supported by grants from the Foundation of Stars, Canadian Institutes of Health Research (CIHR; 201610PJT-377869), Fondation Les Amis d'Elliot, Fondation Lueur d'Espoir pour Ayden, Fondation le Tout pour Loo, Leuco-Action, and Réseau de Médecine Génétique Appliquée of the Fonds de Recherche en Santé du Québec (FRQS). This research was enabled in part by support provided by Compute Canada (computecanada.ca). G. Bernard has received the CIHR New Investigator Salary Award (2017-2022). S. Perrier is supported by the FRQS Doctoral Scholarship, Fondation du Grand défi Pierre Lavoie Doctoral Scholarship, McGill Faculty of Medicine F.S.B. Miller Fellowship, and RI-MUHC Desjardins Studentship in Child Health Research. L. Gauquelin has received scholarships from Can-GARD (Canadian Gene Cure Advanced Therapies for Rare Disease) and R.S. McLaughlin and Teva Canada Innovation Funds from the Faculty of Medicine, Université Laval. M.A. Michell-Robinson is supported by the McGill Faculty of Medicine (MD-PhD Program). T.B. Haack was supported by the German Bundesministerium für Bildung und Forschung through the Juniorverbund in der Systemmedizin "mitOmics" (FKZ01ZX1405C), the intramural fortüne program (\#2435-0-0), and the Deutsche Forschungsgemeinschaft (German Research Foundation) Projektnummer (418081722).

\section{Disclosure}

S. Perrier reports no disclosures. L. Gauquelin has received scholarships from Can-GARD (Canadian Gene Cure Advanced Therapies for Rare Disease) and from the R.S. McLaughlin and Teva Canada Innovation Funds from the Faculty of Medicine, Université Laval. C. Fallet-Bianco, M.K. Dishop, M.A. Michell-Robinson, L.T. Tran, K. Guerrero, L. Darbelli, M. Srour, K. Petrecca, and D.L. Renaud report no disclosures. M. Saito has received compensation from Shire Pharmaceutical (2017) for an unrelated study. S. Cohen reports no disclosures. S. Leiz has received financial compensation for lectures from Desitin, Hamburg. B. Alhaddad, T.B. Haack, I. Tejera-Martin, and F.I. Monton report no disclosures. N. Rodriguez-Espinosa has received research grants from Grifols S.A. D. Pohl has received compensation for consulting, presentations, and support for travel and conference attendance from Bayer-Schering, Biogen, Forward Pharma, Merck Serono, Sanofi, Teva, and Novartis. S. Nageswaran, A. Grefe, and E. Glamuzina report no disclosures. G. Bernard has received compensation for traveling to meetings and advisory boards from Ionis, Shire/Takeda, Children's Hospital of Philadelphia, and Actelion Pharmaceuticals. She served on the scientific advisory board for Ionis (2019) and has received research grants from Shire/Takeda and Bluebird Bio. Go to Neurology.org/NN for full disclosures.

\section{Publication history}

Received by Neurology: Genetics November 6, 2019. Accepted in final form March 25, 2020.

Appendix Authors

\begin{tabular}{|c|c|c|}
\hline Name & Location & Contribution \\
\hline $\begin{array}{l}\text { Stefanie } \\
\text { Perrier, HBSc }\end{array}$ & $\begin{array}{l}\text { McGill University; } \\
\text { Research Institute of the } \\
\text { McGill University Health } \\
\text { Centre, Montreal, QC, } \\
\text { Canada }\end{array}$ & $\begin{array}{l}\text { Designed and } \\
\text { conceptualized the study; } \\
\text { acquisition of data; } \\
\text { analysis and } \\
\text { interpretation of data; and } \\
\text { drafted and revised the } \\
\text { manuscript for intellectual } \\
\text { content }\end{array}$ \\
\hline $\begin{array}{l}\text { Laurence } \\
\text { Gauquelin, } \\
\text { MD, FRCPC }\end{array}$ & $\begin{array}{l}\text { McGill University, } \\
\text { Montreal, QC, Canada; } \\
\text { The Hospital for Sick } \\
\text { Children, University of } \\
\text { Toronto, ON, Canada }\end{array}$ & $\begin{array}{l}\text { Designed and } \\
\text { conceptualized the study; } \\
\text { acquisition of data; } \\
\text { analysis and } \\
\text { interpretation of data; and } \\
\text { drafted and revised the } \\
\text { manuscript for intellectual } \\
\text { content }\end{array}$ \\
\hline
\end{tabular}


Appendix (continued)

\begin{tabular}{lll}
\hline Name & Location & Contribution \\
\hline Catherine & CHU Sainte-Justine, & Acquisition of data; \\
$\begin{array}{l}\text { Fallet-Bianco, } \\
\text { MD }\end{array}$ & $\begin{array}{l}\text { Université de Montreal, } \\
\text { QC, Canada }\end{array}$ & $\begin{array}{l}\text { analysis and } \\
\text { interpretation of data; and } \\
\text { drafted and revised the } \\
\text { manuscript for intellectual } \\
\text { content }\end{array}$ \\
& &
\end{tabular}

\begin{tabular}{lll}
\hline Megan K. & Phoenix Children's & Acquisition of data; \\
Dishop, MD & Hospital, AZ & $\begin{array}{l}\text { interpsis and } \\
\text { intation of data; and } \\
\end{array}$ \\
& & revised the manuscript for
\end{tabular}
intellectual content

\begin{tabular}{lll}
\hline Mackenzie A. & McGill University; & Acquisition of data; analysis \\
Michell- & Research Institute of the & and interpretation of data; \\
Robinson, & McGill University Health & and drafted and revised the \\
MSc & Centre, Montreal, QC, & manuscript for intellectual \\
& Canada & content
\end{tabular}

\begin{tabular}{lll}
\hline $\begin{array}{l}\text { Luan T. Tran, } \\
\text { MSc }\end{array}$ & $\begin{array}{l}\text { McGill University; Research } \\
\text { Institute of the McGill } \\
\text { University Health Centre, } \\
\text { Montreal, QC, Canada }\end{array}$ & $\begin{array}{l}\text { Acquisition of data and } \\
\text { revised the manuscript for } \\
\text { intellectual content }\end{array}$ \\
\hline $\begin{array}{l}\text { Kether } \\
\text { Guerrero, }\end{array}$ & $\begin{array}{l}\text { McGill University; Research } \\
\text { Institute of the McGill }\end{array}$ & $\begin{array}{l}\text { Acquisition of data; } \\
\text { analysis and } \\
\text { MSc }\end{array}$ \\
$\begin{array}{l}\text { University Health Centre, } \\
\text { Montreal, QC, Canada }\end{array}$ & $\begin{array}{l}\text { revised the manuscript for } \\
\text { intellectual content }\end{array}$
\end{tabular}

\begin{tabular}{lll}
\hline Lama & McGill University; & Acquisition of data; \\
Darbelli, PhD & Research Institute of the & analysis and \\
& McGill University Health & interpretation of data; and \\
Centre, Montreal, QC, & drafted and revised the \\
Canada & manuscript for intellectual \\
& & content
\end{tabular}

\begin{tabular}{|c|c|c|}
\hline $\begin{array}{l}\text { Myriam } \\
\text { Srour, MDCM, } \\
\text { PhD }\end{array}$ & $\begin{array}{l}\text { McGill University; Research } \\
\text { Institute of the McGill } \\
\text { University Health Centre, } \\
\text { Montreal, QC, Canada }\end{array}$ & $\begin{array}{l}\text { Acquisition of data and } \\
\text { revised the manuscript for } \\
\text { intellectual content }\end{array}$ \\
\hline $\begin{array}{l}\text { Kevin } \\
\text { Petrecca, MD, } \\
\text { PhD, FRCSC }\end{array}$ & $\begin{array}{l}\text { McGill University; Brain } \\
\text { Tumour Research Center } \\
\text { Montreal Neurological } \\
\text { Institute and Hospital, QC, } \\
\text { Canada }\end{array}$ & $\begin{array}{l}\text { Acquisition of data and } \\
\text { revised the manuscript for } \\
\text { intellectual content }\end{array}$ \\
\hline
\end{tabular}

\begin{tabular}{lll}
\hline $\begin{array}{l}\text { Deborah L. } \\
\text { Renaud, MD }\end{array}$ & $\begin{array}{l}\text { Mayo Clinic, Rochester, } \\
\text { MN }\end{array}$ & $\begin{array}{l}\text { Acquisition of data and } \\
\text { revised the manuscript for } \\
\text { intellectual content }\end{array}$ \\
\hline $\begin{array}{l}\text { Michael } \\
\text { Saito, MD }\end{array}$ & $\begin{array}{l}\text { University of California } \\
\text { Riverside School of } \\
\text { Medicine; Riverside Medical } \\
\text { Clinic, CA }\end{array}$ & $\begin{array}{l}\text { Acquisition of data and } \\
\text { revised the manuscript for } \\
\text { intellectual content }\end{array}$ \\
\hline $\begin{array}{l}\text { Seth Cohen, } \\
\text { MD }\end{array}$ & $\begin{array}{l}\text { Beaver Medical Group, } \\
\text { Redlands, CA }\end{array}$ & $\begin{array}{l}\text { Acquisition of data and } \\
\text { revised the manuscript for } \\
\text { intellectual content }\end{array}$ \\
\hline $\begin{array}{l}\text { Steffen Leiz, } \\
\text { MD }\end{array}$ & $\begin{array}{l}\text { Klinikum Dritter Orden, } \\
\text { Munich, Germany }\end{array}$ & $\begin{array}{l}\text { Acquisition of data and } \\
\text { revised the manuscript for } \\
\text { intellectual content }\end{array}$ \\
\hline $\begin{array}{l}\text { Bader } \\
\text { Alhaddad, } \\
\text { MD }\end{array}$ & $\begin{array}{l}\text { Technische Universität } \\
\text { München, Munich, }\end{array}$ & $\begin{array}{l}\text { Acquisition of data and } \\
\text { revised the manuscript for } \\
\text { intellectual content }\end{array}$ \\
\hline $\begin{array}{l}\text { Germany } \\
\text { Habias B. }\end{array}$ & $\begin{array}{l}\text { Technische Universität } \\
\text { München, Munich, }\end{array}$ & $\begin{array}{l}\text { Acquisition of data and } \\
\text { revised the manuscript for } \\
\text { intellectual content }\end{array}$ \\
& $\begin{array}{l}\text { Germany; Institute of } \\
\text { Medical Genetics and } \\
\text { Applied Genomics, }\end{array}$ & \\
\hline $\begin{array}{l}\text { University of Tübingen, } \\
\text { Germany }\end{array}$ & \\
\hline & & \\
\hline
\end{tabular}

Appendix (continued)

\begin{tabular}{|c|c|c|}
\hline Name & Location & Contribution \\
\hline $\begin{array}{l}\text { Ingrid Tejera- } \\
\text { Martín, MD }\end{array}$ & $\begin{array}{l}\text { Hospital Universitario } \\
\text { Nuestra Señora de } \\
\text { Candelaria, Santa } \\
\text { Cruz de Tenerife, } \\
\text { Canary Islands, } \\
\text { Spain }\end{array}$ & $\begin{array}{l}\text { Acquisition of data and } \\
\text { revised the manuscript for } \\
\text { intellectual content }\end{array}$ \\
\hline $\begin{array}{l}\text { Fernando I. } \\
\text { Monton, MD, } \\
\text { PhD }\end{array}$ & $\begin{array}{l}\text { Hospital Universitario } \\
\text { Nuestra Señora de } \\
\text { Candelaria, Santa Cruz de } \\
\text { Tenerife, Canary Islands, } \\
\text { Spain }\end{array}$ & $\begin{array}{l}\text { Acquisition of data and } \\
\text { revised the manuscript for } \\
\text { intellectual content }\end{array}$ \\
\hline $\begin{array}{l}\text { Norberto } \\
\text { Rodríguez- } \\
\text { Espinosa, MD }\end{array}$ & $\begin{array}{l}\text { Hospital Universitario } \\
\text { Nuestra Señora de } \\
\text { Candelaria, Santa Cruz de } \\
\text { Tenerife, Canary Islands, } \\
\text { Spain }\end{array}$ & $\begin{array}{l}\text { Acquisition of data and } \\
\text { revised the manuscript for } \\
\text { intellectual content }\end{array}$ \\
\hline $\begin{array}{l}\text { Daniela Pohl, } \\
\text { MD, PhD }\end{array}$ & $\begin{array}{l}\text { Children's Hospital of } \\
\text { Eastern Ontario, } \\
\text { University of Ottawa, } \\
\text { Canada }\end{array}$ & $\begin{array}{l}\text { Acquisition of data and } \\
\text { revised the manuscript for } \\
\text { intellectual content }\end{array}$ \\
\hline $\begin{array}{l}\text { Savithri } \\
\text { Nageswaran, } \\
\text { MBBS, MPH }\end{array}$ & $\begin{array}{l}\text { Wake Forest School of } \\
\text { Medicine, Winston-Salem, } \\
\text { NC }\end{array}$ & $\begin{array}{l}\text { Acquisition of data and } \\
\text { revised the manuscript for } \\
\text { intellectual content }\end{array}$ \\
\hline $\begin{array}{l}\text { Annette } \\
\text { Grefe, MD }\end{array}$ & $\begin{array}{l}\text { Wake Forest School of } \\
\text { Medicine, Winston-Salem, } \\
\text { NC }\end{array}$ & $\begin{array}{l}\text { Acquisition of data and } \\
\text { revised the manuscript for } \\
\text { intellectual content }\end{array}$ \\
\hline $\begin{array}{l}\text { Emma } \\
\text { Glamuzina, } \\
\text { MD }\end{array}$ & $\begin{array}{l}\text { Starship Children's } \\
\text { Hospital, Auckland, New } \\
\text { Zealand }\end{array}$ & $\begin{array}{l}\text { Acquisition of data and } \\
\text { revised the manuscript for } \\
\text { intellectual content }\end{array}$ \\
\hline $\begin{array}{l}\text { Geneviève } \\
\text { Bernard, MD, } \\
\text { MSc FRCPC }\end{array}$ & $\begin{array}{l}\text { McGill University; } \\
\text { Research Institute of the } \\
\text { McGill University Health } \\
\text { Centre; Montreal } \\
\text { Children's Hospital and } \\
\text { McGill University Health } \\
\text { Centre, QC, Canada }\end{array}$ & $\begin{array}{l}\text { Designed and } \\
\text { conceptualized the study; } \\
\text { acquisition of data; analysis } \\
\text { and interpretation of data; } \\
\text { revised the manuscript for } \\
\text { intellectual content; and } \\
\text { study supervision }\end{array}$ \\
\hline
\end{tabular}

\section{References}

1. Wolf NI, Vanderver A, van Spaendonk RM, et al. Clinical spectrum of $4 \mathrm{H}$ leukodystrophy caused by POLR3A and POLR3B mutations. Neurology 2014;83: 1898-1905

2. Timmons M, Tsokos M, Asab MA, et al. Peripheral and central hypomyelination with hypogonadotropic hypogonadism and hypodontia. Neurology 2006;67:2066-2069.

3. Bernard G, Vanderver A. POLR3-Related leukodystrophy. In: Adam MP, Ardinger $\mathrm{HH}$, Pagon RA, et al, editors. GeneReviews. Seattle, WA: University of Washington, Seattle; 2017.

4. Vrij-van den Bos S, Hol JA, La Piana R, et al. 4H Leukodystrophy: a brain magnetic resonance imaging scoring system. Neuropediatrics 2017;48:152-160.

5. La Piana R, Tonduti D, Gordish Dressman H, et al.. Brain magnetic resonance imaging (MRI) pattern recognition in Pol III-related leukodystrophies. J Child Neurol 2014;29:214-220.

6. Steenweg ME, Vanderver A, Blaser S, et al.. Magnetic resonance imaging pattern recognition in hypomyelinating disorders. Brain 2010;133:2971-2982.

7. Bernard G, Chouery E, Putorti ML, et al. Mutations of POLR3A encoding a catalytic subunit of RNA polymerase Pol III cause a recessive hypomyelinating leukodystrophy. Am J Hum Genet 2011;89:415-423.

8. Saitsu H, Osaka H, Sasaki M, et al. Mutations in POLR3A and POLR3B encoding RNA Polymerase III subunits cause an autosomal-recessive hypomyelinating leukoencephalopathy. Am J Hum Genet 2011;89:644-651.

9. Daoud H, Tétreault M, Gibson W, et al. Mutations in POLR3A and POLR3B are a major cause of hypomyelinating leukodystrophies with or without dental abnormalities and/or hypogonadotropic hypogonadism. J Med Genet 2013;50:194-197.

10. Thiffault I, Wolf NI, Forget D, et al. Recessive mutations in POLR1C cause a leukodystrophy by impairing biogenesis of RNA polymerase III. Nat Commun 2015;6:7623.

11. Tétreault M, Choquet $\mathrm{K}$, Orcesi S, et al. Recessive mutations in POLR3B, encoding the second largest subunit of Pol III, cause a rare hypomyelinating leukodystrophy. Am J Hum Genet 2011;89:652-655. 
12. Gutierrez M, Thiffault I, Guerrero K, et al. Large exonic deletions in POLR3B gene cause POLR3-related leukodystrophy. Orphanet J Rare Dis 2015;10:69.

13. Dorboz I, Dumay-Odelot H, Boussaid K, et al. Mutation in POLR3K causes hypomyelinating leukodystrophy and abnormal ribosomal RNA regulation. Neurol Genet 2018;4:e289.

14. Jasiak AJ, Armache KJ, Martens B, Jansen RP, Cramer P. Structural biology of RNA polymerase III: subcomplex C17/25 X-ray structure and 11 subunit enzyme model. Mol Cell 2006;23:71-81.

15. Dieci G, Fiorino G, Castelnuovo M, Teichmann M, Pagano A. The expanding RNA polymerase III transcriptome. Trends Genet 2007;23:614-622.

16. Choquet K, Forget D, Meloche E, et al. Leukodystrophy-associated POLR3A mutations down-regulate the RNA polymerase III transcript and important regulatory RNA BC200. J Biol Chem 2019;294:7445-7459.

17. Schiffmann R, van der Knaap MS. Invited article: an MRI-based approach to the diagnosis of white matter disorders. Neurology 2009;72:750-759.

18. La Piana R, Cayami FK, Tran LT, et al. Diffuse hypomyelination is not obligate for POLR3-related disorders. Neurology 2016;86:1622-1626.

19. Cayami FK, Bugiani M, Pouwels PJW, Bernard G, van der Knaap MS, Wolf NI. $4 \mathrm{H}$ leukodystrophy: lessons from 3T imaging. Neuropediatrics 2018;49:112-117.

20. Schulz DM, Giordano DA, Schulz DH. Weights of organs of fetuses and infants. Arch Pathol 1962;74:244-250.

21. Hiraide $\mathrm{T}$, Kubota $\mathrm{K}$, Kono Y, et al. POLR3A variants in striatal involvement without diffuse hypomyelination. Brain Dev 2020;42:363-368.

22. Harting I, Al-Saady M, Krageloh-Mann I, et al. POLR3A variants with striatal involvement and extrapyramidal movement disorder. Neurogenetics 2020;21:121-133.

23. Azmanov DN, Siira SJ, Chamova T, et al. Transcriptome-wide effects of a POLR3A gene mutation in patients with an unusual phenotype of striatal involvement. Hum Mol Genet 2016;25:4302-4314.

24. Wu S, Bai Z, Dong X, et al. Novel mutations of the POLR3A gene caused POLR3-related leukodystrophy in a Chinese family: a case report. BMC Pediatr 2019;19:289.

25. Minnerop M, Kurzwelly D, Wagner H, et al. Hypomorphic mutations in POLR3A are a frequent cause of sporadic and recessive spastic ataxia. Brain 2017;140:1561-1578.

26. Vanderver A, Tonduti D, Bernard G, et al. More than hypomyelination in Pol-III disorder. J Neuropathol Exp Neurol 2013;72:67-75.

27. Abbott JA, Francklyn CS, Robey-Bond SM. Transfer RNA and human disease. Front Genet 2014;5:158.

28. Kapur M, Monaghan CE, Ackerman SL. Regulation of mRNA translation in neurons: a matter of life and death. Neuron 2017;96:616-637.
29. Lee TI, Young RA. Transcriptional regulation and its misregulation in disease. Cell 2013;152:1237-1251.

30. Tahmasebi S, Khoutorsky A, Mathews MB, Sonenberg N. Translation deregulation in human disease. Nat Rev Mol Cell Biol 2018;19:791-807.

31. Mendes MI, Gutierrez Salazar M, Guerrero K, et al. Bi-allelic mutations in EPRS encoding the glutamyl-prolyl-aminoacyl-tRNA synthetase, cause a hypomyelinating leukodystrophy. Am J Hum Genet 2018;102:676-684.

32. Taft RJ, Vanderver A, Leventer RJ, et al. Mutations in DARS cause hypomyelination with brain stem and spinal cord involvement and leg spasticity. Am J Hum Genet 2013;92:774-780.

33. Wolf NI, Salomons GS, Rodenburg RJ, et al. Mutations in RARS cause hypomyelination. Ann Neurol 2014;76:134-139.

34. Feinstein M, Markus B, Noyman I, et al. Pelizaeus-Merzbacher-like disease caused by AIMP1/p43 homozygous mutation. Am J Hum Genet 2010;87: $820-828$.

35. Zhang X, Ling J, Barcia G, et al. Mutations in QARS, encoding glutaminyl-tRNA synthetase, cause progressive microcephaly, cerebral-cerebellar atrophy, and intractable seizures. Am J Hum Genet 2014;94:547-558.

36. Accogli A, Russell L, Sebire G, et al. Pathogenic variants in AIMP1 cause pontocerebellar hypoplasia. Neurogenetics 2019;20:103-108.

37. Ognjenovic J, Simonovic M. Human aminoacyl-tRNA synthetases in diseases of the nervous system. RNA Biol 2018;15:623-634.

38. Friedman J, Smith DE, Issa MY, et al. Biallelic mutations in valyl-tRNA synthetase gene VARS are associated with a progressive neurodevelopmental epileptic encephalopathy. Nat Commun 2019;10:707.

39. Jay AM, Conway RL, Thiffault I, et al. Neonatal progeriod syndrome associated with biallelic truncating variants in POLR3A. Am J Med Genet A 2016;170: 3343-3346.

40. Wambach JA, Wegner DJ, Patni N, et al. Bi-allelic POLR3A loss-of-function variants cause autosomal-recessive wiedemann-rautenstrauch syndrome. Am J Hum Genet 2018;103:968-975.

41. Richards MR, Plummer L, Chan YM, et al. Phenotypic spectrum of POLR3B mutations: isolated hypogonadotropic hypogonadism without neurological or dental anomalies. J Med Genet 2017;54:19-25.

42. Choquet K, Yang S, Moir RD, et al. Absence of neurological abnormalities in mice homozygous for the Polr3a G672E hypomyelinating leukodystrophy mutation. Mol Brain 2017;10:13. 


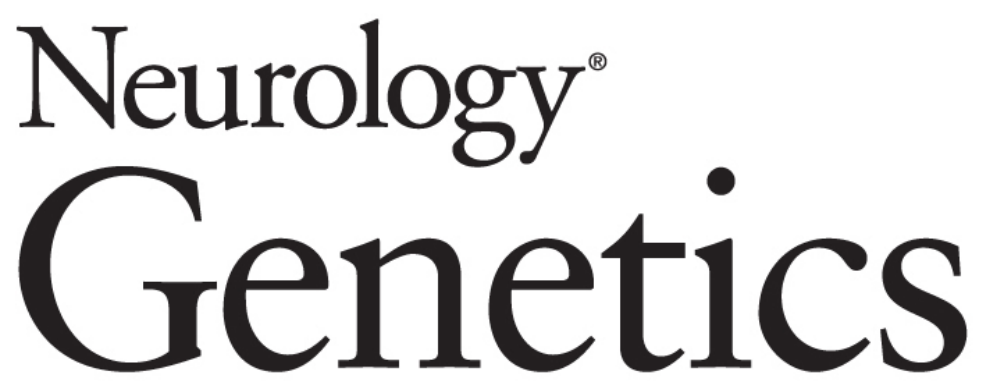

Expanding the phenotypic and molecular spectrum of RNA polymerase III-related leukodystrophy

Stefanie Perrier, Laurence Gauquelin, Catherine Fallet-Bianco, et al. Neurol Genet 2020;6;

DOI 10.1212/NXG.0000000000000425

This information is current as of May 11, 2020

Neurol Genet is an official journal of the American Academy of Neurology. Published since April 2015, it is an open-access, online-only, continuous publication journal. Copyright Copyright ( 2020 The Author(s). Published by Wolters Kluwer Health, Inc. on behalf of the American Academy of Neurology.. All rights reserved. Online ISSN: 2376-7839.

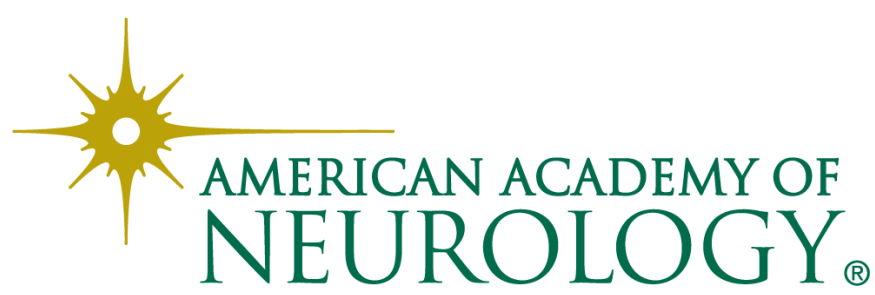




\section{Updated Information \& Services}

References

Citations

Subspecialty Collections

Permissions \& Licensing

Reprints including high resolution figures, can be found at: http://ng.neurology.org/content/6/3/e425.full.html

This article cites 41 articles, 4 of which you can access for free at: http://ng.neurology.org/content/6/3/e425.full.html\#\#ref-list-1

This article has been cited by 1 HighWire-hosted articles: http://ng.neurology.org/content/6/3/e425.full.html\#\#otherarticles

This article, along with others on similar topics, appears in the following collection(s):

\section{All Genetics}

http://ng.neurology.org//cgi/collection/all_genetics

Developmental disorders

http://ng.neurology.org//cgi/collection/developmental_disorders

Leukodystrophies

http://ng.neurology.org//cgi/collection/leukodystrophies

Information about reproducing this article in parts (figures,tables) or in its entirety can be found online at:

http://ng.neurology.org/misc/about.xhtml\#permissions

Information about ordering reprints can be found online:

http://ng.neurology.org/misc/addir.xhtml\#reprintsus

Neurol Genet is an official journal of the American Academy of Neurology. Published since April 2015, it is an open-access, online-only, continuous publication journal. Copyright Copyright $\odot 2020$ The Author(s). Published by Wolters Kluwer Health, Inc. on behalf of the American Academy of Neurology.. All rights reserved. Online ISSN: 2376-7839.

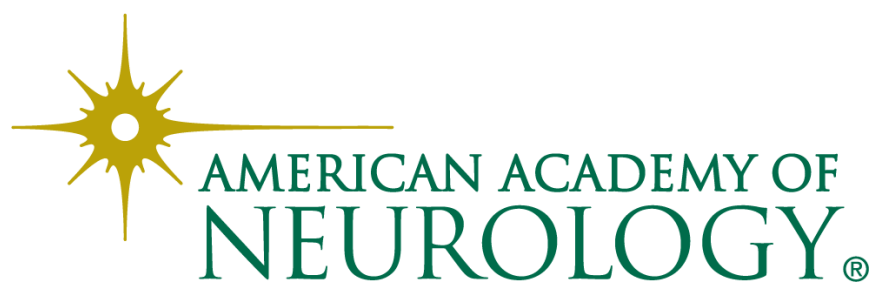

